\title{
Method for Preliminary Estimation of the Critical Power Density in Laser Technological Processes
}

\author{
Lyubomir Lazov \\ Faculty of Engineering \\ Rezekne Academy of Technologies \\ Rezekne, Latvia \\ 1lazov@abv.bg
}

\author{
Nikolay Angelov \\ Department of Physics, Chemistry and \\ Ecology \\ Technical University of Gabrovo \\ Gabrovo, Bulgaria \\ angelov_np@abv.bg
}

\author{
Edmunds Teirumnieks \\ Faculty of Engineering \\ Rezekne Academy of Technologies \\ Rezekne, Latvia \\ edmunds.teirumnieks@rta.lv
}

\begin{abstract}
For a number of new laser technology processes, it is essential to plan an experimental plan for primary experimental engineering activities in terms of quality. The assessment of the critical power density to reach the melting or evaporation temperature of the surface with a suitable theoretical model is an important stage in the development of a particular manufacturing technology. With the help of numerical experiments, this report provides a method for pre-examining the influence of wavelength on the laser technological process. The calculations are performed with a specialized program, running MATLAB. A series of temperature fields were obtained at a change in power density and wavelength at laser impact for concrete types of structural steel. The temperature dependence of the optical and thermo-physical characteristics of the material is also reporded. The analysis is made for laser technology complexes working with lasers emitting in the ultraviolet, visible, near and distant infrared areas. For these wavelengths the critical power density of melting and evaporation is determined.
\end{abstract}

Keywords-laser processing of materials, numerical experiments, temperature fields, structural steel, wavelength, power density.

\section{INTRODUCTION}

The specific properties of laser radiation, such as high monochromaticity, low distortion, coherence, as well as the possibility of achieving high energy density (respectively power density) in the processing area are the main arguments for the successful industrial application of laser sources over the last 58 years. Laser sources generate radiations with wavelength in a wide spectral range, from ultraviolet, visible and infrared, working in continuous and pulsed mode. Today, lasers are widely used in a number of areas of industrial production such as automotive, aircraft, shipbuilding, machine building and more. For marking, engraving, cutting, welding, drilling of holes, thermal annealing, measurements of linear and angular quantities. Other areas of life in which lasers have entered in recent years include communications, medicine, research, agriculture, the food industry, advertising, military, and so on.

Laser technological processes are complex to realising and depend on a number of factors. Some of them are power density, speed, frequency, pulse duration, impact time, pulse power, pulse energy, defocus, number of repetitions, absorption capacity of the material, depth of penetration, etc. For each technological process, material, and laser, preliminary studies must be performed to clarify the role of all factors and to optimize the process [1 - 4] - fig. 1.

The influence of some factors (fill factor, power, velocity and frequency) is investigated for optimizing the marking of barcodes on aluminum surfaces using the $\mathrm{Nd}$ : YAG laser [5].

The role of frequency on the process of marking stainless steel products with the Nd: YAG laser has been investigated, and the working interval for quality marking, has been determined [6].

In [7] analyzes the effect of power, velocity, defocustion, pressure and flow of the auxiliary gas on cutting process with $\mathrm{CO}_{2}$ laser.

In [8] is considered the receiving of seamless laser welds of low carbon and stainless steel sheets. The influence of speed and power on the process is investigated. Technological tables have been compiled with optimal parameters for the studied steels.

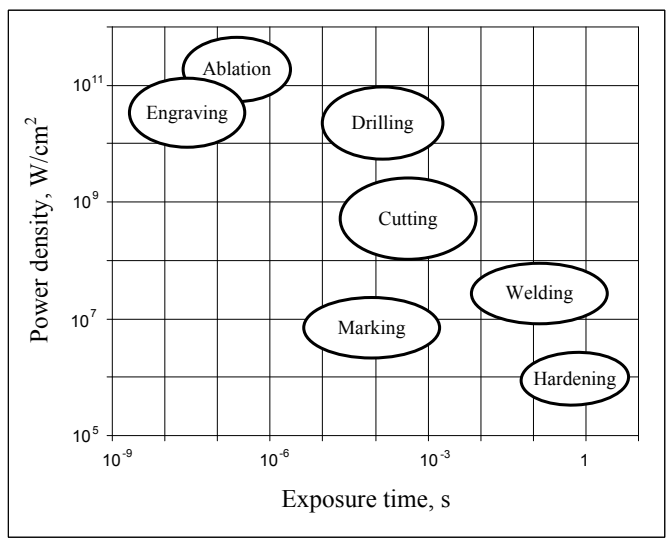

Fig. 1. Diapasons of the power density and time of impact for basic laser technological processes

Research on the determination of optimal technological parameters is mandatory when introducing laser technologies into practice, as the processes are complex and involve a number of processes of the interaction

Print ISSN 1691-5402

Online ISSN 2256-070X

http://dx.doi.org/10.17770/etr2019vol3.4140

(C) 2019 Lyubomir Lazov, Nikolay Angelov, Edmunds Teirumnieks. Published by Rezekne Academy of Technologies.

This is an open access article under the Creative Commons Attribution 4.0 International License. 
of the radiation with the substance (the materials being processed). They can generally be divided into two stages. First stage theoretical studies are related to modeling and simulations of process. The second stage is experimental for determining and achieving the qualitative criteria, pledged in the technology.

The purpose of the publication is to investigate the influence of the laser radiation density and the rate of processing to reach of critical power densities of melting and evaporation for concrete materials (samples) from the industry.

\section{EXPOSITION}

A number of laser technology processes such as hardening, alloying, welding, cladding, marking, engraving, etc. are carried out in the intervals between the temperatures of: quenching $T_{\mathrm{H}}$, melting $T_{\mathrm{m}}$ and evaporation $T_{v}$ of the treated materials - fig. 2 .
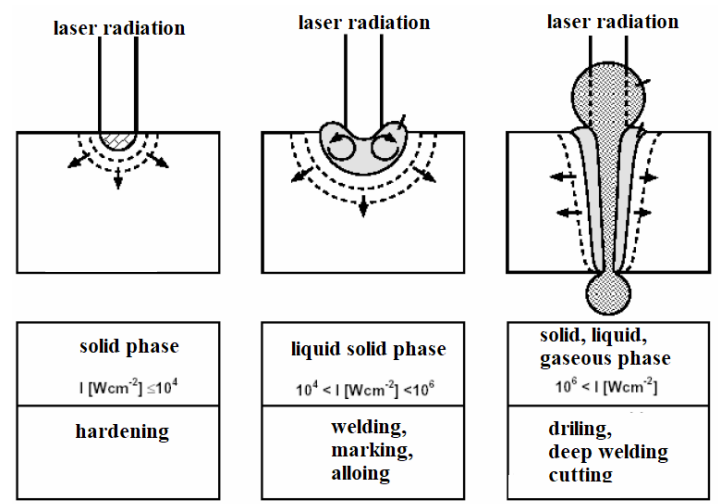

Fig. 2. Mechanism of interaction of the laser radiation with the substance for the different processes

Preliminary numerical experiments and model simulations and analyzes were performed for three types of laser systems and two types of materials.

\section{Laser technological systems}

The researches are for laser technological systems with a $\mathrm{CuBr}$ laser (operating in the visible area), a fiber laser (operating in the near infrared area), a $\mathrm{CO}_{2}$ laser (operating in the far infrared area). In the Table I are showed some parameters of these systems. The fiber laser has higher radiation quality and higher efficiency compared to the other two lasers. All three laser systems have high positioning accuracy and good repeatability.

TABLE I. Basic Parameters of TeChNological systems with CuBr LASER, FIBER LASER AND $\mathrm{CO}_{2}$ LASER

\begin{tabular}{|l|c|c|c|}
\hline $\begin{array}{c}\text { Laser } \\
\text { parameter }\end{array}$ & $\begin{array}{c}\text { CuBr } \\
\text { laser }\end{array}$ & $\begin{array}{c}\text { Fiber } \\
\text { laser }\end{array}$ & $\begin{array}{c}\mathbf{C O}_{2} \\
\text { laser }\end{array}$ \\
\hline Wavelength $\lambda, \mu \mathrm{m}$ & 0,511 & 1,062 & 10,6 \\
\hline Power $P, \mathrm{~W}$ & 20,0 & 40,0 & 100 \\
\hline Frequency $v, \mathrm{kHz}$ & 20,0 & 20 & 50 \\
\hline Pulse duration $\tau, \mathrm{ns}$ & 30 & 250 & 250 \\
\hline Pulse energy $E_{\mathrm{p}}, \mathrm{mJ}$ & 1,00 & 2,00 & 2,00 \\
\hline Pulse power $P_{\mathrm{p}}, \mathrm{kW}$ & 33,3 & 8,00 & 8,00 \\
\hline Beam quality $M^{2}$ & $<1,7$ & $<1,1$ & 10,0 \\
\hline Positioning accuracy, $\mu \mathrm{m}$ & 2,5 & 2,5 & 2,5 \\
\hline
\end{tabular}

\begin{tabular}{|l|l|l|l|}
\hline Efficiency, \% & 10 & 40 & 20 \\
\hline
\end{tabular}

\section{Materials}

Numerical experiments refer to samples of structural steels C45 and 18ChGT. They are widely used in the industry [9]. C45 is used for making gears, crankshafts and camshafts, sprockets, spindles, sealants, cylinders, cams and other parts that are normalized, improved and subjected to surface heat treatment requiring increased strength. From steel $18 \mathrm{ChGT}$ are produced improved or cemented important details, which require increased strength, as well as high surface hardness, which require increased strength, as well as high surface hardness, operating under impact loads. $\mathrm{n}$ the Table II and Table III are showed the temperature dependence of some parameters of the studied steels. They are characterized by high coefficients of thermal conductivity and thermal diffusivity.

TABLE II. TEMPERATURE DEPENDENCE OF CERTAIN PARAMETERS OF CONSTRUCTION STEEL C45.

Legend: $k$ - coefficient of thermal conductivity, $\rho$ - density, $c-$ specific heat capacity, $a$ - coefficient of thermal diffusivity.

\begin{tabular}{|c|c|c|c|c|}
\hline $\boldsymbol{T}, \mathbf{K}$ & $\begin{array}{c}\boldsymbol{k}, \mathbf{W} / \\
(\mathbf{m} \mathbf{K})\end{array}$ & $\mathbf{\rho}, \mathbf{~ k g} / \mathbf{m}^{3}$ & $\mathbf{c}, \mathbf{J} /(\mathbf{k g} \cdot \mathbf{K})$ & $\mathbf{a}, \mathbf{~ m}^{2} / \mathbf{s}$ \\
\hline 293 & 49 & 7826 & 457 & $1,37.10^{-5}$ \\
\hline 373 & 48 & 7799 & 473 & $1,35 \cdot 10^{-5}$ \\
\hline 473 & 47 & 7769 & 494 & $1,22.10^{-5}$ \\
\hline 573 & 44 & 7735 & 515 & $1,10.10^{-5}$ \\
\hline 673 & 41 & 7698 & 536 & $9,94.10^{-6}$ \\
\hline 773 & 39 & 7662 & 583 & $8,73 \cdot 10^{-6}$ \\
\hline 873 & 36 & 7625 & 578 & $8,17.10^{-6}$ \\
\hline 973 & 31 & 7587 & 611 & $6,69 \cdot 10^{-6}$ \\
\hline 1073 & 27 & 7595 & 720 & $4,94.10^{-6}$ \\
\hline 1173 & 26 & 7565 & 708 & $4,85.10^{-6}$ \\
\hline
\end{tabular}

TABLE III. TEMPERATURE DEPENDENCE OF CERTAIN PARAMETERS OF CONSTRUCTION STEEL $18 \mathrm{CHGT}$.

\begin{tabular}{|c|c|c|c|c|}
\hline $\boldsymbol{T}, \mathbf{K}$ & $\begin{array}{c}\boldsymbol{k}, \mathbf{W} / \\
(\mathbf{m} \cdot \mathbf{K})\end{array}$ & $\mathbf{\rho}, \mathbf{k g} / \mathbf{m}^{\mathbf{3}}$ & $\mathbf{c}, \mathbf{J} / \mathbf{k g . K})$ & $\mathbf{a}, \mathbf{~ m}^{2} / \mathbf{s}$ \\
\hline 293 & 37 & 7800 & 485 & $9,78 \cdot 10^{-6}$ \\
\hline 373 & 38 & 7773 & 495 & $9,88 \cdot 10^{-6}$ \\
\hline 473 & 38 & 7743 & 508 & $9,66.10^{-6}$ \\
\hline 573 & 37 & 7709 & 525 & $9,14.10^{-6}$ \\
\hline 673 & 35 & 7672 & 537 & $8,50.10^{-6}$ \\
\hline 773 & 34 & 7636 & 567 & $7,85 \cdot 10^{-6}$ \\
\hline 873 & 31 & 7599 & 588 & $6,94 \cdot 10^{-6}$ \\
\hline 973 & 30 & 7561 & 626 & $6,34.10^{-6}$ \\
\hline 1073 & 29 & 7569 & 705 & $5,43 \cdot 10^{-6}$ \\
\hline
\end{tabular}

\section{Numerical experiments}

To determine the critical values of the power density of melting $q_{\text {Scrm }}$ and evaporation $q_{\text {Scrv }}$, numerical experiments with the program TEMPERATURFELD3D [10] were carried out. It is a specialized program for obtaining temperature fields in the area of laser impact. The calculations refer to the examined technological systems with $\mathrm{CuBr}$ laser, fiber optic laser, $\mathrm{CO}_{2}$ laser [11-13] and structural steels C45 and 18ChGT. The temperature dependence of some parameters of steels (according to Table II and Table III) is recorded.

\section{- for $\mathrm{CuBr}$ laser}

In Fig. 3 and Fig. 4 are presented graphics of the dependencies of the critical power densities of melting $q_{\text {Sкрm }}$ and evaporation $q_{\text {Sкр }}$ from the speed for steels C45 and $18 \mathrm{ChGT}$. From the obtained results, the following 
conclusions can be drawn:

- The critical power densities of melting and evaporation increment non-linearly with increasing of speed for structural steels C45 and 18ChGT with speed in the interval $v \in[20 ; 100] \mathrm{mm} / \mathrm{s}$;

- The rate of increase in critical power density of melting is

for interval $v \in[20 ; 60] \mathrm{mm} / \mathrm{s}$

$7,55.10^{8}\left(\mathrm{~W} / \mathrm{m}^{2}\right) /(\mathrm{mm} / \mathrm{s})$ for steel $\mathrm{C} 45$;

$8,82 \cdot 10^{8}\left(\mathrm{~W} / \mathrm{m}^{2}\right) /(\mathrm{mm} / \mathrm{s})$ for steel $18 \mathrm{ChGT}$;

for interval $v \in[60 ; 100] \mathrm{mm} / \mathrm{s}$

$5,18.10^{8}\left(\mathrm{~W} / \mathrm{m}^{2}\right) /(\mathrm{mm} / \mathrm{s})$ for steel $\mathrm{C} 45$;

$6,12.10^{8}\left(\mathrm{~W} / \mathrm{m}^{2}\right) /(\mathrm{mm} / \mathrm{s})$ for steel $18 \mathrm{ChGT}$;

- The rate of increase in critical power density of evaporation is

for interval $v \in[20 ; 60] \mathrm{mm} / \mathrm{s}$

$12,0.10^{8}\left(\mathrm{~W} / \mathrm{m}^{2}\right) /(\mathrm{mm} / \mathrm{s})$ for steel $\mathrm{C} 45$;

$14,2.10^{8}\left(\mathrm{~W} / \mathrm{m}^{2}\right) /(\mathrm{mm} / \mathrm{s})$ for steel $18 \mathrm{ChGT}$;

for interval $v \in[60 ; 100] \mathrm{mm} / \mathrm{s}$

$8,25.10^{8}\left(\mathrm{~W} / \mathrm{m}^{2}\right) /(\mathrm{mm} / \mathrm{s})$ for steel $\mathrm{C} 45$;

$9,75.10^{8}\left(\mathrm{~W} / \mathrm{m}^{2}\right) /(\mathrm{mm} / \mathrm{s})$ for steel $18 \mathrm{ChGT}$;

- For structural alloy steel $18 \mathrm{ChGT}$, the critical values of power densities of melting and evaporation density are about $17 \%$ greater than for structural carbon steel C45. The reasons for this are the higher melting and evaporation temperatures of steel $18 \mathrm{ChGT}$.

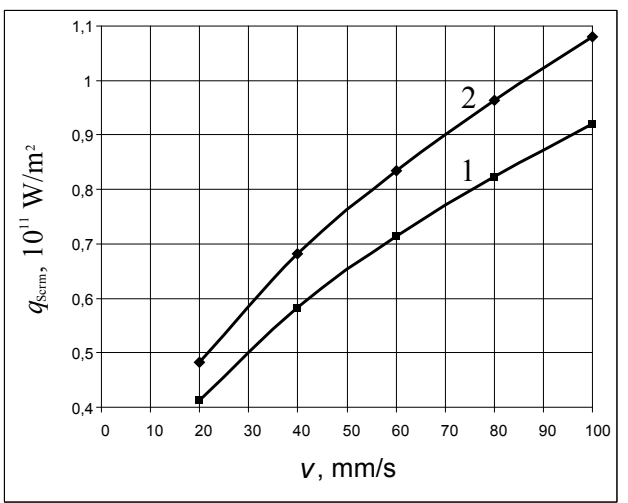

Fig. 3. Graphics of dependence of critical power density of melting from speed for $\mathrm{CuBr}$ laser for: 1 - steel $\mathrm{C} 45 ; \quad 2$ - steel $18 \mathrm{ChGT}$

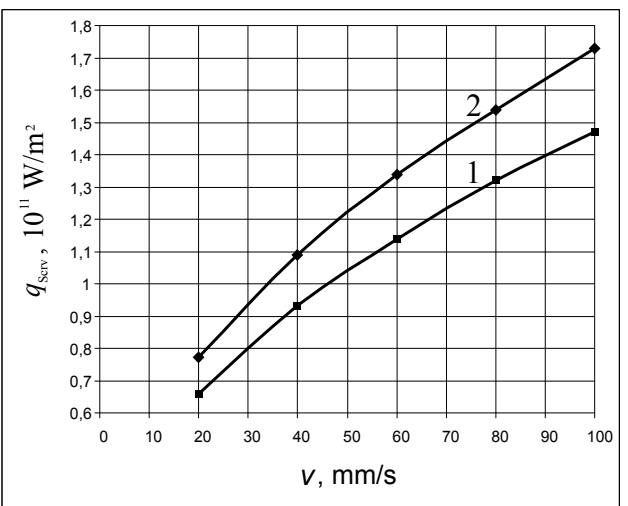

Fig. 4. Graphics of dependence of critical power density of evaporation from speed for $\mathrm{CuBr}$ laser for: 1 -steel $\mathrm{C} 45 ; 2$-steel $18 \mathrm{ChGT}$

\section{- for fiber laser}

In Fig. 3 and Fig. 4 are showed graphics of the dependencies of the critical power densities of melting $q_{\text {Sкрm }}$ and evaporation $q_{\text {Sкрv }}$ from the speed for steels C45 and $18 \mathrm{ChGT}$ From the obtained graphics, it follows:

- The critical power densities of melting and evaporation increment non-linearly with increasing of speed for both steels;

- The rate of increase in critical power density of melting is

for interval $v \in[20 ; 60] \mathrm{mm} / \mathrm{s}$

$0,94.10^{9}\left(\mathrm{~W} / \mathrm{m}^{2}\right) /(\mathrm{mm} / \mathrm{s})$ for steel $\mathrm{C} 45$;

$1,09.10^{9}\left(\mathrm{~W} / \mathrm{m}^{2}\right) /(\mathrm{mm} / \mathrm{s})$ for steel $18 \mathrm{ChGT}$;

for intrval $v \in[60 ; 100] \mathrm{mm} / \mathrm{s}$

$0,64.10^{9}\left(\mathrm{~W} / \mathrm{m}^{2}\right) /(\mathrm{mm} / \mathrm{s})$ for steel $\mathrm{C} 45$;

$0,75.10^{9}\left(\mathrm{~W} / \mathrm{m}^{2}\right) /(\mathrm{mm} / \mathrm{s})$ for steel $18 \mathrm{ChGT}$;

- The rate of increase in critical power density of evaporation is

for interval $v \in[20 ; 60] \mathrm{mm} / \mathrm{s}$

$1,52.10^{9}\left(\mathrm{~W} / \mathrm{m}^{2}\right) /(\mathrm{mm} / \mathrm{s})$ for steel $\mathrm{C} 45$;

$1,74.10^{9}\left(\mathrm{~W} / \mathrm{m}^{2}\right) /(\mathrm{mm} / \mathrm{s})$ for steel $18 \mathrm{ChGT}$;

for interval $v \in[60 ; 100] \mathrm{mm} / \mathrm{s}$

$1,02.10^{9}\left(\mathrm{~W} / \mathrm{m}^{2}\right) /(\mathrm{mm} / \mathrm{s})$ for steel $\mathrm{C} 45$;

$1,25.10^{9}\left(\mathrm{~W} / \mathrm{m}^{2}\right) /(\mathrm{mm} / \mathrm{s})$ for steel $18 \mathrm{ChGT}$;

- For structural alloy steel $18 \mathrm{ChGT}$, the critical values of power densities of melting and evaporation density are about $17 \%$ greater than for structural carbon steel C45. The explanation is the same as with the $\mathrm{CuBr}$ laser;

- Higher values of critical power densities of melting and evaporation for the fiber laser compared to the $\mathrm{CuBr}$ laser are because the radiation in visible area is better absorbed from the steels from that in the nearinfrared area.

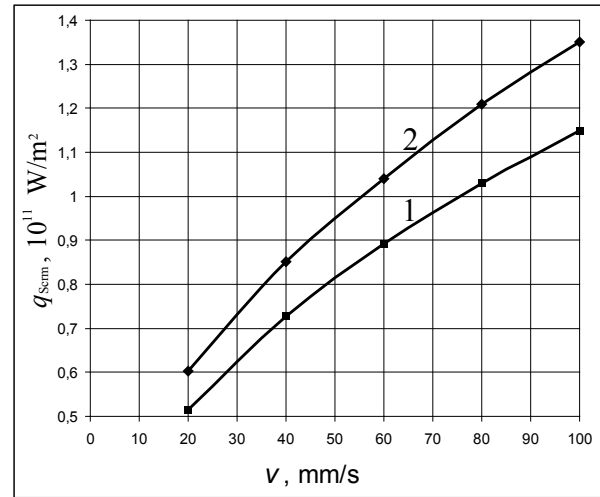

Fig. 5. Graphics of dependence of critical power density of melting from speed for fiber laser for: 1 - steel C45;2 - steel 18ChGT

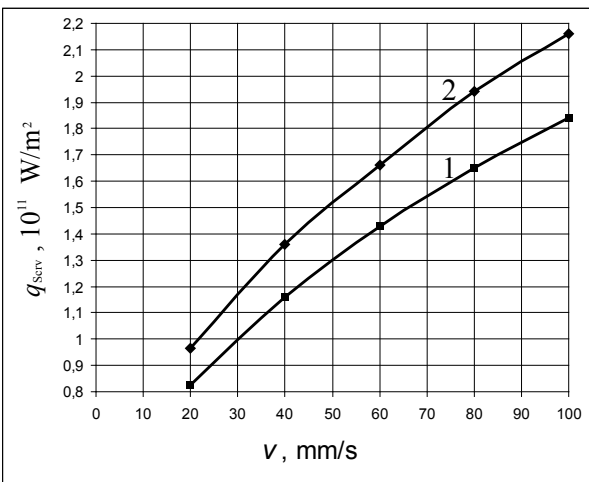

Fig. 6. Graphics of dependence of critical power density of evaporation from speed for fiber laser for: 1 - steel $\mathrm{C} 45 ; 2$ - steel $18 \mathrm{ChGT}$ 
Fig. 9. $2-$ steel $18 \mathrm{ChGT}$

\section{- for $\mathrm{CO}_{2}$ laser}

From the numerical experiments obtained, the dependencies of the critical power densities of melting $q_{\text {Scrm }}$ and evaporation $q_{\text {Scrv }}$ from the speed for steels C45 and 18ChGT (Fig. 7 and Fig. 8) were presented. The following conclusions can be drawn:

- The critical power densities of melting and evaporation increment non-linearly with increasing of speed for both studied steels;

- The rate of increase in critical power density of melting is

for interval $v \in[20 ; 60] \mathrm{mm} / \mathrm{s}$

$1,32.10^{9}\left(\mathrm{~W} / \mathrm{m}^{2}\right) /(\mathrm{mm} / \mathrm{s})$ for steel $\mathrm{C} 45$;

$1,54.10^{9}\left(\mathrm{~W} / \mathrm{m}^{2}\right) /(\mathrm{mm} / \mathrm{s})$ for steel $18 \mathrm{ChGT}$;

for interval $v \in[60 ; 100] \mathrm{mm} / \mathrm{s}$

$0,90.10^{9}\left(\mathrm{~W} / \mathrm{m}^{2}\right) /(\mathrm{mm} / \mathrm{s})$ for steel $\mathrm{C} 45$;

$1,08.10^{9}\left(\mathrm{~W} / \mathrm{m}^{2}\right) /(\mathrm{mm} / \mathrm{s})$ for steel $18 \mathrm{ChGT}$;

- The rate of increase in critical power density of evaporation is

for interval $v \in[20 ; 60] \mathrm{mm} / \mathrm{s}$

$2,10.10^{9}\left(\mathrm{~W} / \mathrm{m}^{2}\right) /(\mathrm{mm} / \mathrm{s})$ for steel $\mathrm{C} 45$;

$2,48.10^{9}\left(\mathrm{~W} / \mathrm{m}^{2}\right) /(\mathrm{mm} / \mathrm{s})$ for steel $18 \mathrm{ChGT}$;

for interval $v \in[60 ; 100] \mathrm{mm} / \mathrm{s}$

$1,45.10^{9}\left(\mathrm{~W} / \mathrm{m}^{2}\right) /(\mathrm{mm} / \mathrm{s})$ for steel $\mathrm{C} 45$;

$1,70.10^{9}\left(\mathrm{~W} / \mathrm{m}^{2}\right) /(\mathrm{mm} / \mathrm{s})$ for steel $18 \mathrm{ChGT}$;

- For structural alloy steel $18 \mathrm{ChGT}$, the critical values of power densities of melting and evaporation density are greater than for structural carbon steel C45.;

- Critical power densities upon impact to $\mathrm{CO}_{2}$ laser Критичните плътности на мощността при въздействие с $\mathrm{CO}_{2}$ лазер are considerably larger than the other two lasers - with about $40 \%$ greater than fiber laser and about $75 \%$ greater than those for a $\mathrm{CuBr}$ laser.

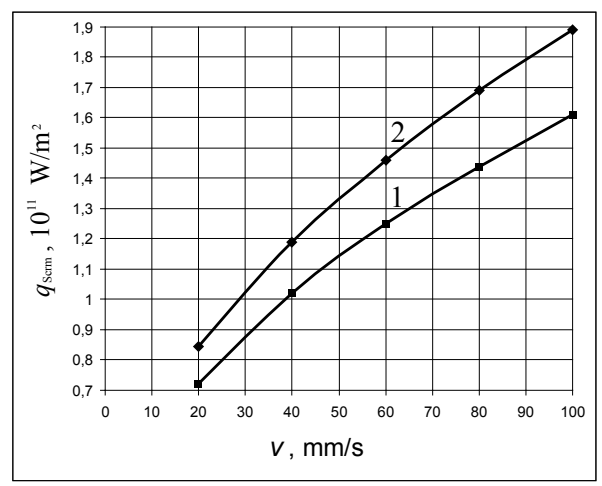

Fig. 7. Graphics of dependence of critical power density of melting from speed for CO2-laser for: 1 - steel C45;2-steel 18ChGT

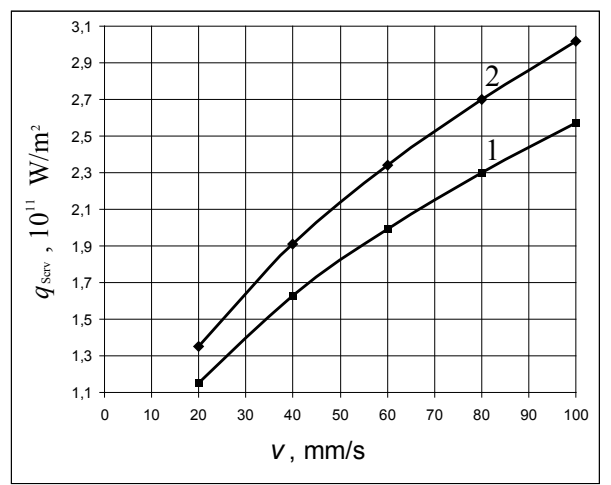

Fig. 8. Graphics of dependence of critical power density of evaporation from speed for $\mathrm{CO}_{2}$ - laser for: 1 - steel $\mathrm{C} 45$;

\section{Summary}

The pre-operating intervals of the power density for the laser technological processes hardening, marking and welding by melting for the three lasers and the two structural steels are given in Table IV.

THE PRE-OPERATING INTERVALS OF THE POWER DENSITY FOR THE LASER TECHNOLOGICAL PROCESSES HARDENING, MARKING AND WELDING BY MELTING

\begin{tabular}{|c|c|c|c|}
\cline { 2 - 4 } \multicolumn{1}{c|}{} & Steel & C45 & 18ChGT \\
\hline Laser & Speed & & \\
\hline \multirow{2}{*}{$\begin{array}{c}\text { CuBr } \\
\text { laser }\end{array}$} & 20 & $4,12.10^{10} \div 6,59.10^{10}$ & $4,82.10^{10} \div 7,72.10^{10}$ \\
\cline { 2 - 4 } & 40 & $5,83.10^{10} \div 9,32.10^{10}$ & $6,82.10^{10} \div 1,09.10^{11}$ \\
\hline & 60 & $7,14.10^{10} \div 1,14.10^{11}$ & $8,35.10^{10} \div 1,34.10^{11}$ \\
\hline & 80 & $8,24.10^{10} \div 1,32.10^{11}$ & $9,64.10^{10} \div 1,54.10^{11}$ \\
\hline & 100 & $9,21.10^{10} \div 1,47.10^{11}$ & $1,08.10^{11} \div 1,73.10^{11}$ \\
\hline \multirow{2}{*}{$\begin{array}{c}\text { Fiber } \\
\text { laser }\end{array}$} & 20 & $5,15.10^{10} \div 8,24.10^{10}$ & $6,03.10^{10} \div 9,62.10^{10}$ \\
\cline { 2 - 4 } & 40 & $7,28.10^{10} \div 1,16.10^{11}$ & $8,52.10^{10} \div 1,36.10^{11}$ \\
\hline & 60 & $8,92.10^{10} \div 1,43.10^{11}$ & $1,04.10^{11} \div 1,66.10^{11}$ \\
\hline & 80 & $1,03.10^{11} \div 1,65.10^{11}$ & $1,21.10^{11} \div 1,94.10^{11}$ \\
\hline & 100 & $1,15.10^{11} \div 1,84.10^{11}$ & $1,35.10^{11} \div 2,16.10^{11}$ \\
\hline \multirow{2}{*}{$\begin{array}{c}\mathrm{CO}_{2} \\
\text { laser }\end{array}$} & 20 & $7,21.10^{10} \div 1,15.10^{11}$ & $8,44.10^{10} \div 1,35.10^{11}$ \\
\hline & 40 & $1,02.10^{11} \div 1,63.10^{11}$ & $1,19.10^{11} \div 1,91.10^{11}$ \\
\hline & 60 & $1,25.10^{11} \div 1,99.10^{11}$ & $1,46.10^{11} \div 2,34.10^{11}$ \\
\hline & 80 & $1,44.10^{11} \div 2,30.10^{11}$ & $1,69.10^{11} \div 2,70.10^{11}$ \\
\hline & 100 & $1,61.10^{11} \div 2,57.10^{11}$ & $1,89.10^{11} \div 3,02.10^{11}$ \\
\hline
\end{tabular}

The pre-operating intervals of the power density for the laser technological processes ablation, marking by evaporation, engraving, drilling and cutting of thin sheets for the three lasers and the two structural steels are given in Table V.

Table IV. The Pre-Operating Intervals Of The Power TABle IV. The Pre-Operating Intervals Of The Power
Density For The Laser Technological Processes Ablation, Marking By Evaporation, Engraving, Drilling And Cutting OF THIN SHEETS

\begin{tabular}{|c|c|c|c|}
\cline { 2 - 4 } \multicolumn{1}{c|}{} & Steel & C45 & 18ChGT \\
\hline Laser & Speed & & \\
\hline $\begin{array}{c}\text { CuBr } \\
\text { laser }\end{array}$ & 20 & $6,59.10^{10} \div 2,08.10^{11}$ & $7,72.10^{10} \div 2,08.10^{11}$ \\
\cline { 2 - 4 } & 40 & $9,32.10^{10} \div 2,08.10^{11}$ & $1,09.10^{11} \div 2,08.10^{11}$ \\
\hline & 60 & $1,14.10^{11} \div 2,08.10^{11}$ & $1,34.10^{11} \div 2,08.10^{11}$ \\
\hline & 80 & $1,32.10^{11} \div 2,08.10^{11}$ & $1,54.10^{11} \div 2,08.10^{11}$ \\
\hline \multirow{2}{*}{$\begin{array}{c}\text { Fiber } \\
\text { laser }\end{array}$} & 20 & $8,24.10^{10} \div 3,18.10^{11}$ & $9,62.10^{10} \div 3,18.10^{11}$ \\
\cline { 2 - 4 } & 40 & $1,16.10^{11} \div 3,18.10^{11}$ & $1,36.10^{11} \div 3,18.10^{11}$ \\
\hline & 60 & $1,43.10^{11} \div 3,18.10^{11}$ & $1,66.10^{11} \div 3,18.10^{11}$ \\
\hline & 80 & $1,65.10^{11} \div 3,18.10^{11}$ & $1,94.10^{11} \div 3,18.10^{11}$ \\
\hline & 100 & $1,84.10^{11} \div 3,18.10^{11}$ & $2,16.10^{11} \div 3,18.10^{11}$ \\
\hline \multirow{2}{*}{$\begin{array}{c}\mathrm{CO}_{2} \\
\text { laser }\end{array}$} & 20 & $1,15.10^{11} \div 3,60.10^{11}$ & $1,35.10^{11} \div 3,60.10^{11}$ \\
\cline { 2 - 4 } & 40 & $1,63.10^{11} \div 3,60.10^{11}$ & $1,91.10^{11} \div 3,60.10^{11}$ \\
\hline & 60 & $1,99.10^{11} \div 3,60.10^{11}$ & $2,34.10^{11} \div 3,60.10^{11}$ \\
\hline & 80 & $2,30.10^{11} \div 3,60.10^{11}$ & $2,60.10^{11} \div 3,60.10^{11}$ \\
\hline & 100 & $2,57.10^{11} \div 3,60.10^{11}$ & $3,02.10^{11} \div 3,60.10^{11}$ \\
\hline
\end{tabular}

\section{CONCLUSION}

The obtained critical power densities of melting and evaporation and pre-operating intervals of power density for the investigated technological processes help to plan real experiments in the study of concrete laser technological processes. The results will be in help of:

- operators of laser industrial processes in the industry who will use the pre-operating intervals of power 
density in their work;

- engineers-technologists to optimize specific technological processes and to be able to quickly implement new products on which to implement laser technologies.

Similar studies can be made to investigate the impact of other basic technological factors (pulse energy, impulse power, impulse response, pulse duration, defocusing, etc.) onto processes of laser processing.

\section{REFERENCES}

[1] Sobotova, L., Demec P. (2015), Laser Marking of Metal Materials, Modern Machinery Science Journal, December 2015, 808-812

[2] Valiulin A., Gorniy S., Grechco Y., Patrov M., Yudin K., Yurevich V. Lazerna markirovka materialov. Nauchno-technicheskij zhurnal Fotonika, 2007, 3, pp 16-22 (in Russian)

[3] Angelov N. Optimizacija na procesa markirane s lazerno lychenie na obrazci ot instrumentalna stomana. Disertacionen trud za pridobivane na stepen doktor. TU-Gabrovo, 2011 (in Bulgarian)

[4] Pauli, G., The Method behind the Mark, Small Arms Survey, Number 1, December 2010

[5] Jianmei Li, Aiqun Wang, Yusong Wuab, ZhuoMa, Xinxin Fang, LiangTao, Experimental investigation and mathematical modeling of laser marking two-dimensional barcodes on surfaces of aluminum alloy, Journal of Manufacturing Processes, Volume 21, January 2016, pp 141-152

[6] Qi, J., K. Wang, Y. Zhu (2003), A study on the laser marking process of stainless steel, Journal of Materials Processing Technology, 2003, 20 August, Volume 139, Issues 1-3, 273-276

[7] Senthilkumar, V., Laser cutting process - A Review International Journal of Darshan Institute on Engineering Research \& Emerging Technologies, Vol. 3, No. 1, 2014

[8] Blecher, J., T. Palmer, T. Debroy, Mitigation of Root Defect in Laser and Hybrid Laser-Arc Welding, Welding Journal, 94(3),73-82, March 2015

[9] www.splav-kharkov.com/main.php

[10] Belev I. Sreda za presmyatane na lazerno inducirani temperaturni poleta. Diplomna rabota, TU-Gabrovo, 2009 (in Bulgarian)

[11] www.pulsligth.net

[12] www.axsys.de

[13] www.spilasers.com 